\title{
Matrix Metalloproteinase 2: A Possible Role inTooth Development and Eruption
}

\author{
Metaloproteinasa de matriz 2: \\ Un posible papel en el desarrollo dental y la erupción
}

Nathália G. Sandoval DDS, MSc ${ }^{1}$; Nayra S. C. Lima DDS, MSc ${ }^{1}$; Willian G. Bautz DDS, PhD'; Leticia N. Gama-de-Souza DDS, PhD¹; Karla L. A. Coburn DDS, PhD

1. Health Sciences Center, Federal University of Espirito Santo (UFES), Vitória, Brazil.

Correspondence to: Dra. Karla Loureiro Almeida Coburn - karlaloureiro25@hotmail.com

Received: 10-X-2018

Accepted: 16-XI-2018

Published Online First: 26-XI-2018

DOI: 10.15517/IJDS.V0I0.35327

ABSTRACT

Introduction: Tooth development results from a highly coordinated epithelial-mesenchyme interaction in which mesenchyme cells originate the dental papilla and dental follicle, while ectodermal cells originate the enamel organ. Simultaneously, bone tissue is formed around the developing tooth, trapping it in a bony crypt. Tooth eruption requires the resorption of the coronal part of the bony crypt, followed by degradation of the lamina propria, most likely by metalloproteinases (MMPs) activity. Objectives: The aim of this research was to determine MMP-2 expression in the dental germ cells (ameloblasts, odontoblasts, dental papilla and dental follicle) and surrounding tissues (alveolar bone and lamina propria) of rat molars throughout the eruptive process. Material and Methods: A total of 24 rats $(4,6,9,11,14$ and 16 days old) were used in this study. MMP-2 was detected through immunohistochemistry. A qualitative analysis was performed to investigate the expression of MMP2 in the dental germ cells, lamina propria, and coronal and basal regions of the bony crypt. Results: MMP-2 expression was observed in the dental papilla cells, dental follicle, ameloblasts, odontoblasts and bone cells from the coronal and basal regions of the bony crypt. MMP-2 was also detected in the lamina propria during the mucosal penetration stage of tooth eruption. Conclusion: We conclude that MMP-2 may be important for the extracellular matrix rearrangement necessary for tooth development and secretion of its mineralized tissues. We also conclude that MMP-2 may play a role in the extensive tissue remodeling during the intra-and-extra-osseous phases of the tooth eruption process.

\section{KEYWORDS}

Matrix Metalloproteinase 2; Odontogenesis; Ameloblasts; Odontoblasts;

Tooth eruption; Bone remodeling.

SANDOVAL N., LIMA N., BAUTZ W., GAMA-DE-SOUZA L., COBURN K.., 2018: Matrix Metalloproteinase 2: A Possible Role inTooth Development and Eruption.-ODOVTOS-Int. J. Dental Sc., 21-1 (January-April): 41-51. 


\section{RESUMEN}

Introducción: el desarrollo del diente resulta de una interacción epitelial-mesénquima altamente coordinada en la cual las células mesénquima originan la papila dental y el folículo dental, mientras que las células ectodérmicas originan el órgano del esmalte. Simultáneamente, el tejido óseo se forma alrededor del diente en desarrollo y lo atrapa en una cripta ósea. La erupción dentaria requiere la resorción de la parte coronal de la cripta ósea, seguida de la degradación de la lámina propia, muy probablemente por la actividad metaloproteinasas (MMPs). Objetivos: el objetivo de esta investigación fue determinar la expresión de MMP-2 en las células germinales dentales (ameloblastos, odontoblastos, papila dentaria y folículo dentario) y tejidos circundantes (hueso alveolar y lámina propia) de molares de rata a lo largo del proceso eruptivo. Material y métodos: en este estudio se utilizó un total de 24 ratas $(4,6,9,11,14$ y 16 días de edad). MMP-2 se detectó a través de inmunohistoquímica. Un análisis cualitativo fue realizado para investigar la expresión de MMP-2 en las células de germen dentales, el lámina propria, y las regiones coronales y basales de la cripta ósea. Resultados: la expresión de MMP2 fue observada en las células de la papila dental, el folículo dental, el ameloblastos, el odontoblastos y las células del las regiones basales y coronales de la cripta ósea. La expresión de MMP-2 también se detectó en la lámina propia durante la etapa de penetración de la mucosa de la erupción dental. Conclusión: Concluimos que MMP-2 puede ser importante para el cambio extracelular de la matriz necesario para el desarrollo del diente y la secreción de sus tejidos mineralizados. También concluimos que MMP-2 puede desempeñar un papel en la remodelación extensa del tejido durante las fases intra y extraósea del proceso de erupción dental.

\section{PALABRAS CLAVE}

Matriz metaloproteinasa 2; La odontogénesis; Ameloblastos; Odontoblastos; Erupción dental; Remodelación ósea.

\section{INTRODUCTION}

Dental development involves a reciprocal activation between ectodermal cells that originate the oral epithelium and the underlying mesenchyme, under the regency of conserved signaling pathways. The formation of the dental crown precedes that of the root and it is defined by the folding of the epithelium, constituting the bud, cap and bell stages (1). The final shape of the crown is defined at the bell stage, formed by a dental papilla, derived from the mesenchymal cells, and the enamel organ, originated from the ectodermal cells (2). The enamel organ is formed by the outer epithelium, stellate reticulum, stratum intermedium and inner epithelium, which will latter differentiate into ameloblasts, responsible for enamel formation. At the periphery of the dental papilla lies the odontoblasts, cells responsible for dentin formation (3). The tooth germ is surrounded by the dental follicle, a loose connective tissue sac derived from mesenchyme that will later develop into the periodontal ligament (4).

As the tooth forms, bone trabeculae are formed around it, establishing a bony crypt that surrounds the developing tooth. Once crown formation is complete, the tooth initiates an active movement toward the oral cavity, constituting the eruptive movement (3). The dental follicle has been considered a key element for the regulation of bone-remodeling processes during tooth eruption, controlling bone resorption in the coronal part of the crypt and bone deposition at the base of the crypt 
(5). Tooth eruption depends on the establishment of an eruption pathway, which is achieved by the removal of the coronal bone and the connective tissue interposed between the tooth and the oral cavity (6).

Matrix metalloproteinases (MMPs) are $\mathrm{Zn}^{++}$-dependent proteolytic enzymes with a wide range of substrates and are therefore responsible for the degradation of most of the extracellular matrix components (7). MMP-2, also known as "gelatinase A," is capable of digesting collagens type I, II, III, IV, V, VII, X, XI and gelatin (8), and its importance for the degradation of loose connective tissues has been reported (9-10). MMP-2, like most MMPs, is secreted as a proenzyme that is activated by forming a complex with the tissue inhibitor of metalloproteases 2 (TIMP-2). This complex is a substrate for the membrane type-1 MMP (MMP-14), and the activation of proMMP-2 occurs through the proteolytical removal of its prodomain (11-12).

The epithelial-mesenchymal interactions that determine tooth morphogenesis, as well as the remodeling of bone and lamina propria during the eruptive process, require the action of enzymes capable of modifying the microenvironment of the extracellular matrix. The involvement of MMPs in these processes has not yet been fully established, thus, the aim of this work was to evaluate the expression of MMP-2 in the dental germ and its surrounding tissues, throughout the eruptive process.

\section{MATERIAL AND METHODS}

ANIMALS

This work was performed according to the Ethical Principles of Animal Experimentation adopted by the Ethics Committee on Animal Use of the Federal University of Espirito Santo, Brazil (CEUA-UFES), being approved on 12/04/2015 under license number 85/2015.
A total of 24 Wistar rats (Rattus norvegicus) aged $4,6,9,11,14$ and 16 days old were used in this study (four animals of each age). The animals were provided by the Health Sciences Center facility and were maintained at constant room temperature $\left(22-24^{\circ} \mathrm{C}\right)$ under a $12: 12$ light/dark cycle, with free access to water and food (Labina, Purina, Brazil).

\section{PARAFFIN EMBEDDING PROCEDURES}

The animals were anesthetized by intraperitoneal injection with ketamine $(30 \mathrm{mg} /$ $\mathrm{kg})$ and xylazine $(3 \mathrm{mg} / \mathrm{kg})$, and euthanized by decapitation. The maxillae were removed, dissected and the fragments containing the first molars were fixed at room temperature for 48 hours in $4 \%$ formaldehyde solution buffered with $0.1 \mathrm{M}$ sodium phosphate, pH 7.2. Next, the jaws were decalcified in $7 \%$ EDTA solution containing $0.5 \%$ formaldehyde buffered with $0.1 \mathrm{M}$ sodium phosphate, $\mathrm{pH} 7.2$, for 40 days, and after this period, the specimens were processed to be embedded in paraffin. The paraffin blocks were submitted to microtomy to obtain non-serial sections with $3 \mu \mathrm{m}$ thickness for immunohistochemistry.

\section{IMMUNOHISTOCHEMISTRY}

The sections obtained by the microtomy were deparaffinized in an oven at $60^{\circ} \mathrm{C}$ for 40 min, followed by diaphanization and rehydration. The formic pigment was removed with ammonium hydroxide solution (10\%) in ethanol (95\%), and then the slides were subjected to antigen recovery using a citrate buffer solution (10 mM citric acid and $0.05 \%$ Tween 20 with $\mathrm{pH} 6$ ), heated between $90^{\circ}$ and $95^{\circ} \mathrm{C}$ for 30 minutes. Novocastra Peroxidase Block (Leica Biosystems, Buffalo Grove, IL, USA) was used to neutralize endogenous peroxidase. The polymer-detection system was NovoLink Novocastra (Leica Biosystems Newcastle Ltd, Newcastle Upon Tyne, NE, United Kingdom). The primary antibody used was anti-MMP-2 (Calbiochem, San Diego, CA, 
USA), diluted 1:200 and incubated for 60 minutes in a humidified chamber at room temperature. As a negative control, the incubation step with primary antibodies was performed using a non-immune serum instead. DAB (3.3-diaminobenzidine tetrahydrochloride, Sigma-Aldrich, St. Louis, M0, USA) was used to develop the peroxidase activity and the slides were counterstained with Mayer's Hematoxylin.

\section{ANALYSIS}

MMP-2 expression in dental germ cells and surrounding tissues was evaluated via qualitative descriptive analysis, therefore no statistical analysis was performed in this research. Based on the intensity of the immunostaining in each of the structures evaluated the expression of MMP-2 was considered negative, weak, moderate or strong. Four animals were used of each age $(04,06,09$, 11,14 and 16 days old) with four sections of each animal analyzed. The slides were examined under light microscope (Olympus AX70, Olympus America Inc., Melville, NY, USA) and the selected sections were examined and photographed with an AxioCam ERc5s (Carl Zeiss Vision GmbH, Jena, Germany) using AxioVision Release 4.8.2 (Carl Zeiss Vision $\mathrm{GmbH}$, Jena, Germany) with the images saved in TIF and ZIV formats.

\section{RESULTS}

\section{MMP-2 EXPRESSION ON LAMINA PROPRIA AND ALVEOLAR BONE}

In four- and six-day-old rats, the lamina propria was still thick, and weak MMP-2 expression could be detected in their cells (Figure 1B). In nineand 11-day-old animals, MMP-2 expression became more evident. In 14-day-old animals, the cusp tips of the tooth penetrated the lamina propria, which at this stage presented as a thin layer. In 16-day-old animals, the lamina propria was limited to small regions with strong MMP-2 expression.

\section{CORONAL REGION OF ALVEOLAR BONY CRYPT}

In four-day-old animals, a thick layer of bone tissue was seen in the coronal part of the crypt that surrounded the dental germ. Osteoblasts and osteocytes presented a uniform cytoplasmic expression of MMP-2. In six-day-old animals, strong expression of MMP-2 was observed in osteoclasts (Figure 1C). Osteoblasts continued with the same expression pattern observed in the previous age. At nine days old, MMP-2 expression was still observed in osteoblasts, osteocytes and osteoclasts, and the bone started to show signs of resorption, given that some bone trabeculae became thinner. In 11-dayold animals, MMP-2 expression in osteocytes was strong, and an obvious increase in bone resorption was detected. In 14-day-old animals, few thin bone trabeculae were observed, and at 16 days old, the bone tissue was totally resorbed.

\section{BASE OF THE BONY CRYPT}

Four-day-old animals showed weak MMP2 expression in the osteocytes and osteoblasts observed at the base of the bony crypt. Moreover, the expression in the osteocytes was not homogeneous. There was a small amount of bone matrix and few osteocytes, characterizing the early formation of bone trabeculae. Six-day-old animals showed more developed bone trabeculae with an increased number of osteoblasts, which were expressing MMP-2. Nine-day-old animals had thicker bone trabeculae and an increased number of osteoblasts, which presented strong MMP-2 expression. Eleven- and 14-day-old animals presented similar expression pattern to those described above (nine days), but bone deposition was even more evident in the 14-day-old animals. In the 16-dayold animals, osteocytes and osteoblasts showed 
strong MMP-2 expression (Figure 1D), and the bone matrix was distinctly thicker.

\section{MMP-2 EXPRESSION IN THE TOOTH GERM STELLATE RETICULUM}

Four and six-day-old animals exhibited a well-developed stellate reticulum, with starshaped cells expressing weakly MMP-2 and large intercellular spaces (Figure 2A). Stellate reticulum from nine-day-old animals was slightly reduced compared to that of the previous ages, and its cells exhibited moderate MMP-2 expression. Stellate reticulum from 11 and 14-day-old animals was greatly reduced, and the remaining cells showed moderate-to-weak expression of MMP-2. In 16-day-old animals, the stellate reticulum was completely involuted.

\section{AMELOBLASTS}

A thin layer of dentin and enamel was already observed in four and six-day-old animals (Figure 1A). The ameloblasts were developed and polarized, characterizing the secretory phase of the enamel matrix. At this stage, MMP-2 expression in ameloblasts was weak. Secretory ameloblasts exhibited moderate expression of MMP-2 in sixday-old animals. Nine-day-old animals showed strong MMP-2 expression in all ameloblasts. It was observed in 11-day-old animals that the enamel began to undergo maturation in some areas, evidenced by its loss during histological processing. The ameloblasts presented strong MMP-2 expression, but not uniform. (Figure 2C). In 14-day-old animals, the enamel was already mature and was almost completely lost during histological processing. The ameloblasts were slightly decreased in size, due to their involution, and exhibited a weak expression of MMP-2. In the 16-day-old animals, the ameloblasts could not be distinguished, since they were fused to the remaining cells of the enamel organ, establishing the reduced enamel epithelium.

\section{DENTAL PAPILLA AND ODONTOBLASTS}

Four-day-old animals presented a diffuse MMP-2 expression in the mesenchymal cells of the dental papilla. From six days onwards, it was possible to observe that this expression was more evident in the peripheral part of the papilla, near the odontoblastic layer. MMP-2 expression was more pronounced in the secretory pole of the odontoblasts. From nine to 14 days, a remarkable increase in the thickness of the dentin layer was observed, and the expression of MMP-2 was strong in the dental papilla cells and also in the odontoblasts (Figure 2D).

\section{DENTAL FOLLICLE}

From nine- to 14-day-old animals, dental follicle cells exhibited a strong expression of MMP2 (Figure 2B). Later in the 16-day-old animals, MMP-2 expression was moderate. 

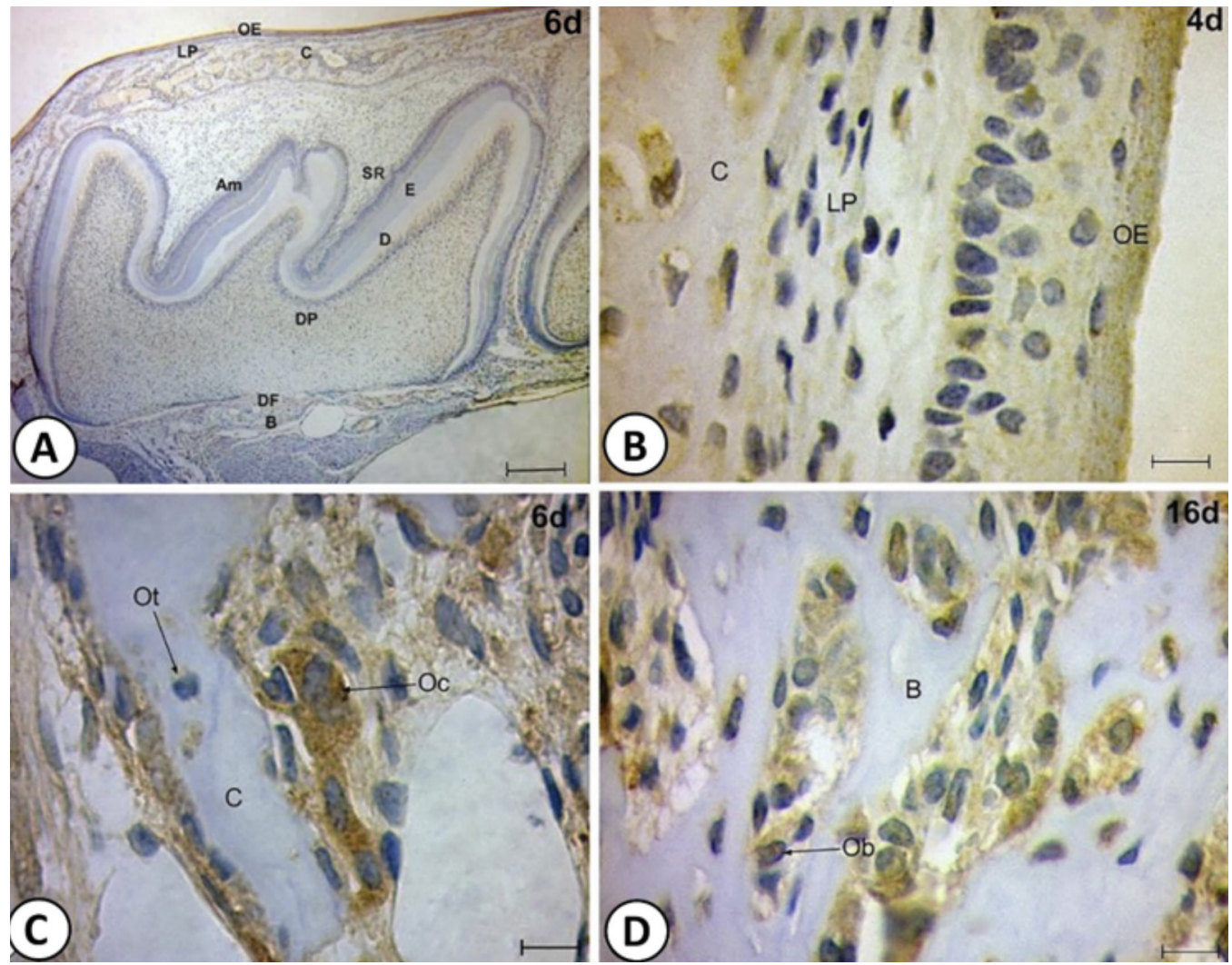

Figure 1. MMP-2 expression in alveolar bone and lamina propria. A: Sagittal section of a tooth germ and surrounding tissues showing oral epithelium (OE), lamina propria (LP), coronal region of bony crypt (coronal bone, C), stellate reticulum (SR), ameloblasts (Am), enamel (E), dentin (D), dental papilla (DP), dental follicle (DF) and basal region of bony crypt (basal bone, B), Scale bar: $100 \mu \mathrm{m}$. B: Higher magnification of MMP-2 expression in lamina propria and coronal bone (four-day-old animal). C: Higher magnification of MMP-2 expression in osteocytes (Ot) and osteoclasts $(\mathrm{Oc})$ in coronal bone (six-day-old animal). D: Higher magnification of MMP-2 expression in osteoblasts (Ob) in basal bone (16-day-old). B-C: Scale bar $5 \mu \mathrm{m}$. 

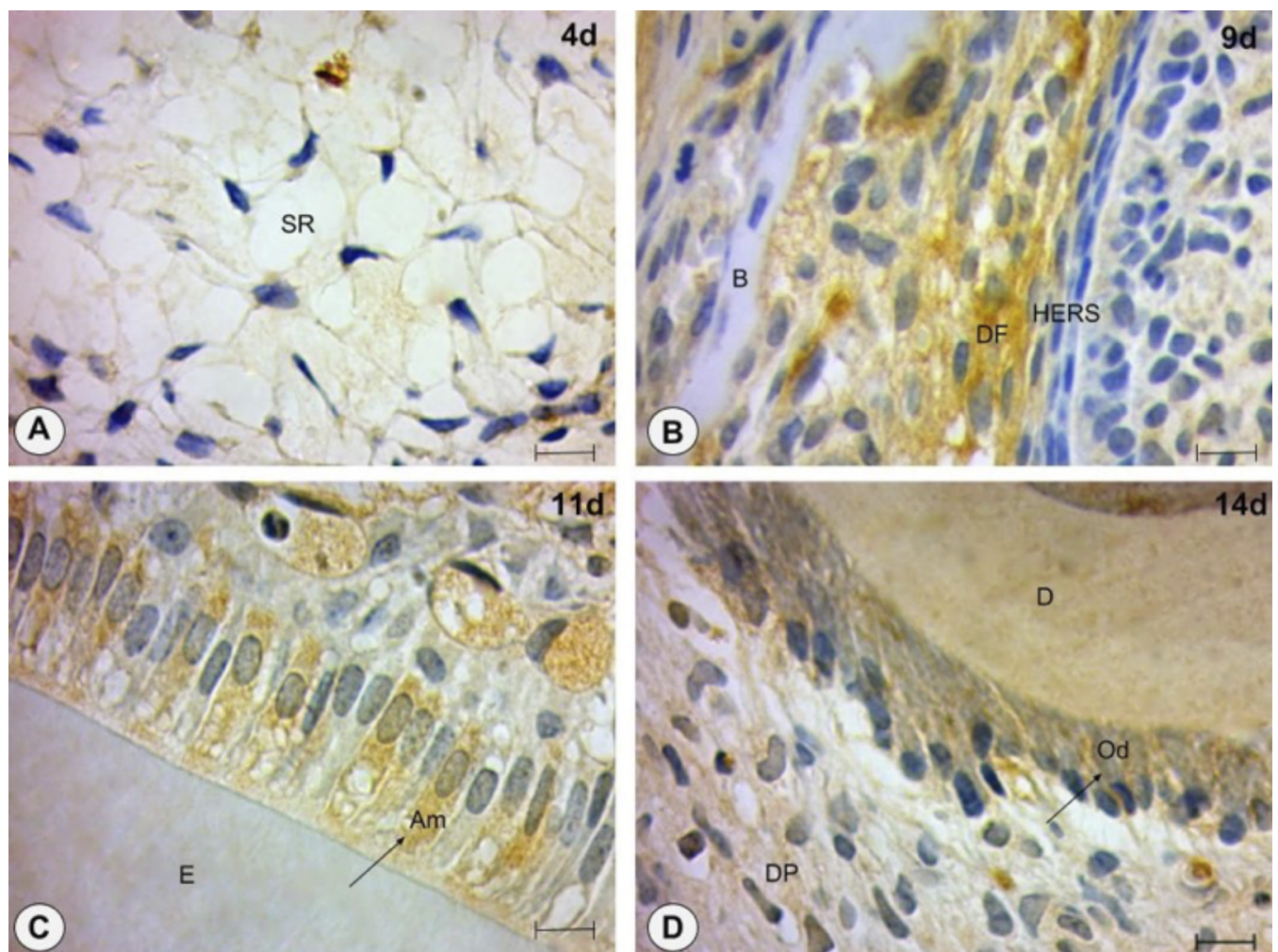

Figure 2. MMP-2 expression in the dental germ. A: Stellate reticulum cells (SR) expressing MMP-2 in four-day-old animals. B: Dental follicle (DF) cells next to Hertwig's epithelial root sheath in nine-day-old animals. C: Ameloblasts (Am) expressing MMP-2 in 11-day-old animals. (E): enamel. D: Odontoblasts (Od) and dental papilla (DP) cells expressing MMP-2 in 14-day-old animals. (D): dentin. Scale bar: $5 \mu \mathrm{m}$. 


\section{DISCUSSION}

Dental development and the eruptive process are highly complex events involving the interaction of cells and extracellular matrix associated with tissue remodeling. Dental eruption depends on the removal of the bone and lamina propria interposed between the dental germ and the oral epithelium, with several studies pointing to the importance of MMPs in these processes (12-15).

Our results demonstrate that the lamina propria undergoes intense degradation which can be noticed by the reduction of its thickness. The increased expression of MMP-2 suggests that this metalloproteinase plays a role in the removal of the extracellular components of the connective tissue of lamina propria. Since MMP-2 expression was markedly stronger in the lamina propria of older animals, when the extra-osseous phase of the eruption process takes place, it is possible that the proteolytic activity of MMP-2 is especially important to tissue remodeling during this period.

The role of the dental follicle in the induction of bone remodeling during the eruptive process is already well-established $(4,16)$. Our results showed a strong expression of MMP-2 in the dental follicle cells of nine, 11 and 14-day-old animals, correlating to the period in which intense bone resorption is also detected. The expression of MMP-2 in follicle cells at the specified ages supports the hypothesis that MMP-2 is involved in the induction of bone resorption during the intra-osseous phase of the eruptive process. More specifically, the release of MMP-2 by dental follicle cells may be related to the recruitment of osteoclast precursor cells to the coronal region of the bony crypt, contributing to its resorption. This idea is supported by previous studies that identified MMPs as necessary to the migration of osteoclasts precursors to the resorption sites (17).
The importance of MMPs for the initiation of bone resorption has been previously demonstrated (14) and MMP-2 transcripts have already been detected in osteoclasts in the basal and coronal regions of the bony crypt throughout the eruptive process of mice (18). The strong MMP-2 expression observed in osteoclasts in our study suggests that MMP-2 might be responsible for osteoclastic activity during the eruptive process, allowing the removal of the bone interposed between the tooth and the oral cavity. Although osteoclasts are key cells responsible for bone resorption, previous studies (19) have shown that osteoblasts may also play a supportive role in this process through the removal of the organic matrix prior to osteoclastic activity. This could explain the MMP-2 expression detected in osteoblasts near the bone remodeling regions analyzed in this study. Interestingly, MMP-2 expression was also observed in osteocytes, which reinforces the role of these cells in the organization and maintenance of the bone matrix, especially during bone remodeling. The expression of MMP2 in osteocytes has been suggested as important to promoting the degradation of the extracellular matrix and thus to forming the canaliculi of the bone matrix (20).

Regarding tooth development, after the onset of dentin deposition the enamel organ reduces in size, mainly due to the involution of the stellate reticulum. The reduction of its thickness has been described as a result of apoptosis, followed by the removal of cellular debris and extracellular matrix by macrophages (21-22). Our results showed MMP-2 expression on stellate reticulum cells, suggesting that the degradation of the extracellular matrix may be due to the MMP-2 proteolytic activity, contributing to the stellate reticulum involution.

In agreement with other studies, (23), we detected the expression of MMP-2 in the apical pole of differentiated ameloblasts, strongly indicating a 
role of MMP-2 during enamel formation. Since this expression became stronger as enamel deposition reached its final stages, it is possible that MMP2 is more specifically related to the maturation phase of enamel synthesis. The importance of MMP-2 for the enamel-maturation processes has been demonstrated by in vitro studies, based on MMP-2's ability to cleave amelogenin, the main organic constituent of the enamel matrix (24).

We also detected the expression of MMP2 in odontoblasts, which is most likely related to MMP-2 proteolytic activity during dentin matrix maturation and mineralization, as observed in previous studies (25). The expression of MMP-2 in ameloblasts and odontoblasts reinforces the idea suggested by Boittin et al (26), that MMPs act in the degradation, remodeling and maturation of dentin and enamel. When MMPs were inhibited, a series of mineralization defects were detected in the matrix of these tissues (26).

The expression pattern of MMP- 2 in the dental papilla cells was initially diffuse, concentrating in subsequent stages to the peripheral region of the papilla. Other studies have also found strong expression of MMP-2 in the dental papilla throughout rat tooth development (27). It has been suggested that MMP-2 initially contributes to the remodeling of mesenchymal tissue of dental papilla through gelatinase activity. After the odontoblastic differentiation and early deposition of pre-dentin, MMP-2 is also responsible for the degradation of the basement membrane between odontoblasts and ameloblasts through the digestion of type IV collagen (27,29-30).

Limitations of the present study include the use of a single observer, which could contribute to increased subjectivity during data collection and analysis. Although the temporal analysis of MMP-2 expression pattern provides valuable and detailed information regarding a possible function of this enzyme during tooth development and eruption, loss of function experiments would provide more precise information about the requirement of MMP-2 during these processes.

Within the limitations of this research, our results place MMP-2 as a potential player on the proteolytic activity required during tooth development and eruption. Further studies using animal models in which this MMP is inhibited or absent could provide additional insights regarding the role of MMP-2 in the aforementioned processes.

\section{CONCLUSION}

Based on the MMP-2 expression on several tissues from the tooth germ, we conclude that MMP-2 may be important for the extracellular matrix remodeling during tooth development and secretion of its mineralized tissues. We also conclude that MMP-2 may play a role in the extensive tissue remodeling during the intra- and extra-osseous phases of the tooth eruption process.

\section{AKNOWLEGMENTS}

To Espirito Santo Research Foundation (FAPES), for having granted a graduate scholarship to Sandoval (Process number 66610788/2014).

\section{REFERENCES}

1. Thesleff I. Current understanding of the process of tooth formation: transfer from the laboratory to the clinic. Aust Dent J. 2014; 59 (1): 48-54.

2. Thesleff I. Epithelial-mesenchymal signalling regulating tooth morphogenesis. J Cell Sci. 2003; 116: 1647-8.

3. Nanci A. Ten Cate's oral histology: development, structure, and function. 8th edition. Mosby, 2013.

4. Wise G. E. Cellular and molecular basis of tooth eruption. Orthod Craniofac Res. 2009; 12: 67-73. 
5. Wise G. E., He H., Gutierrez D. L., Ring S., Yao S. Requirement of alveolar bone formation for eruption of rat molars. Eur $\mathrm{J}$ Oral Sci. 2011; 119 (5): 333-8.

6. Wise G., King G. Mechanisms of tooth eruption and orthodontic tooth movement. J Dent Res. 2008; 414-434.

7. Klein T., Bischoff R. Physiology and pathophysiology of matrix metalloproteases. Amino Acids. 2011; 41 (2): 271-90.

8. Ning C., Min H., Raouf A. K. Matrix metalloproteinases and tissue inhibitors of metalloproteinases: structure, function, and biochemistry. Circ Res. 2003; 92 (8): 827-39.

9. Allan J., Docherty A., Barker P., Huskisson N., Reynolds J.,Murphy G. Binding of gelatinases $\mathrm{A}$ and $\mathrm{B}$ to type-I collagen and other matrix components. Biochem J. 1995; 309: 299-306.

10. Creemers L., Jansen I., Docherty A., Reynolds J., Beertsen W., Everts V. Gelatinase A(MMP2) and cysteine proteinases are essential for the degradation of collagen in soft connective tissue. Matrix Biol. 1998; 17 (1): 35-46.

11. Deryugina E. I., Ratnikov B., Monosov E., Postnova T. I., DiScipio R., Smith J. W. et al. MT1-MMP initiates activation of proMMP-2 and integrin alphavbeta3 promotes maturation of MMP-2 in breast carcinoma cells. Exp Cell Res. 2001; 263: 209-23.

12. Beertsen W.,Holmbeck K., NiehofA., Bianco P., Chrysovergis K., Birkedal-Hansen H. et al. On the role of MT1-MMP, a matrix metalloproteinase essential to collagen remodeling, in murine molar eruption and root growth. Euro J Oral Sci. 2002; 110 (6): 445-51.

13. Maruyal Y., Sasano Y., Takahashi I., Kagaymama M., Mayanagi H. Expression of extracelular matrix molecules, MMPs and TIMPs in alveolar bone, cementum and periodontal ligaments during rat tooth eruption. J Electron Microsc. 2003; 52 (6): 593-604.
14. Gomes J., Omar N., dos Santos Neves J., Narvaes E., Novaes P. Immunolocalization and activity of the MMP-9 and MMP-2 in odontogenic region of the rat incisor tooth after post shortening procedure. J mol hist. 2011; 42 (2): 153-9.

15. Cerri P. S., Pereira Júnior J. A., Biselli N. B., Sasso-Cerri E. Mast cells and MMP 9 in the lamina propria during eruption of rat molars: quantitative and immunohistochemical evaluation. J anat. 2010; 116-25.

16. Wise G. E., Frazier-Bowers S., D'Souza R. N. Cellular, molecular, and genetic determinants of tooth eruption. Crit Rev Oral Biol Med. 2002; 13 (4): 323-34.

17. Blavier L., and Delaisse, J. M. Matrix metalloproteinases are obligatory for the migration of preosteoclasts to the developing marrow cavity of primitive long bones. J. Cell Sci. 1995; 108, 3649-59.

18. Huang X., Zhao Y., Zhang F., Han, P. Comparative study of gene expression during tooth eruption and orthodontic tooth movement in mice. Oral Dis. 2009;15 (8): 573-9.

19. SodekJ.,Overall C.Matrix metalloproteinases in periodontal tissue remodelling. Matrix Supp.1991; 1: 352-62.

20. Inoue K., Mikuni-Takagaki Y., Oikawa K., Itoh T., Inada M., Noguchi T. et al. A crucial role for matrix metalloproteinase 2 in osteocytic canalicular formation and bone metabolism. J Biol Chem. 2006. 3; 281 (44): 33814-24.

21. Gómez M., Munõz: Histologia e embriologia bucodental. $2 \mathrm{~d}$ ed. Rio de Janeiro: Guanabara Koogan, 2006.

22. Baratella L., Arana-Chavez V., Katchburian E. Macrophages and apoptosis in the stellate reticulum of the rat enamel organ. J. Anat. 2000; 197:303-6.

23. Yoshiba N., Yoshiba K., Stoetzel C., Schmitt F., Cam Y., Ruch V., et al. Temporospatial 
Gene Expression and Protein Localization of Matrix Metalloproteinases and Their Inhibitors During Mouse Molar Tooth Development. Devl Dyn. 2003; 228 (1): 105-12.

24. Caron C., Xue J., Sun X., Simmer J. P., Bartlett J. D. Gelatinase A (MMP-2) in developing tooth tissues and amelogenin hydrolysis. J Dent Res. 2001; 80 (7): 1660-4.

25. Satoyoshi M., Kawata A., Koizumi T., Inoue K., Itohara S., Teranaka T., Mikuni-Takagaki Y. Matrix metalloproteinase-2 in dentin matrix mineralization. J Endod. 2001; 27 (7): 462-6.

26. Boittin K., Fridmanb R., Fanchona P., Septiera D., Goldberga M., Menashic S. Matrix metalloproteinase inhibition impairs the processing, formation and mineralization of dental tissues during mouse molar development. Exp Cell Res. 2005; 304 (2): 493-505.

27. Sahlberg C., Reponen P., Tryggvason K., Thesleff I. Association between the expression of murine $72 \mathrm{kda}$ type IV collagenase by odontoblasts and basement membrane degradation during mouse tooth development. Archis Oral Biof. 1992; 37: 1021-30.

28. Cotrim P., Andrade C., Line S., Almeida O., Coletta R. Expression and activity of matrix metalloproteinase-2 (MMP-2) in the development of rat first molar tooth germ. Braz Dent J. 2002; 13(2): 97-102.

29. Reponen P., Sahlberg C., Huhtalas P., Hurskainenl T., Thesleff I., Tryggvason K. Molecular Cloning of Murine 72-kDa Type IV Collagenase and Its Expression during Mouse Development. J Biol Chem. 1991; 267: 7856-7862.

30. Sahlberg C., Reponen P., Tryggvason K., Thesleff I. Timp-1, -2 and -3 show coexpression with gelatinases $\mathrm{A}$ and $\mathrm{B}$ during mouse tooth morphogenesis. Eur J Oral Sci. 1999; 107 (2): 21-30. 